\title{
The Mid-Eighteenth-Century Georgic and Agricultural Improvement
}

'We ought [...] to persuade ourselves', writes a contributor to a collection of Select Essays on Commerce, Agriculture, Mines, Fisheries, and Other Useful Subjects (1754), 'that let the present method of cultivating lands be never so good, it will always be possible to improve it'. 'This intellectually curious attitude to economic progress is typical of the culmination of the early period of agricultural improvement between 1730 and $1760,{ }^{2}$ which marked a transfer of activity from parliamentary intervention and amateur enthusiasm to the more sophisticated efforts of an emerging 'rural professional class'. ${ }^{3}$ Progressive landowners subsidised the ventures of their tenantry and invested in experimental model farms, whilst those with particularly extensive resources exploited the mineral potential of their estates. ${ }^{4}$ The enterprise of the aristocracy, though, was hardly exceptional. Predominantly, the changing topography of eighteenth-century Britain was the result of the localised ventures of tenants, agents and smallholders. In the east of England, literate farmers with their own land experimented with fodder crops introduced from Holland, implementing the new four-course rotation system promoted by Viscount Townshend on his lands at Raynham in Norfolk. On lighter soils, grassland was converted into arable which returned profitable yields of corn, and heavier clay-based soils were converted to pasture.

The process of land conversion was greatly accelerated by the replacement of localised statutory enclosure with enclosure by parliamentary act, which built up momentum towards the middle of the century. Enclosure permitted farmers to manage their land as their own interests directed, rather than in deference to traditional common rights, and the result was an efficient progress towards the eradication of waste lands and long fallow periods. Extensive reclamation of wild heathlands occurred in Norfolk, where Arthur Young noticed in 1768 that the country between the estates of Holkham and Houghton had been seized 'by the spirit of improvement' and enclosed into manageable holdings, which were now 'yielding an hundred times the produce' of formerly. ${ }^{5}$ The enterprise of literate farmers was in large part encouraged by the proliferation of agricultural journals and societies. John Houghton's series of Collections (1681-3; 1692-1703) offered the first informative farmers' periodical, and practical handbooks like William Ellis's The Modern Husbandman (1731) and Young's The Farmer's Kalendar (1770) went through several editions. Edinburgh's Society of Improvers (established 1723) and the British Society of Arts (1754) sponsored agricultural innovations and offered rewards for local enterprise.

The spirit of enterprise and innovation, though, is tempered in eighteenth-century agricultural literature by a surprising degree of reliance on the common ground of classical letters. Contemporary practical treatises turn naturally to Greek and Roman sources for information, and their dependence is one facet of a broader seventeenth- and eighteenth-century revival of interest in poetry of the classical didactic tradition, and in Virgil's Georgics in particular. In the Middle Ages and early Renaissance, didactic poetry in English owed little to classical models, so that Thomas Tusser could produce his Five Hundred Points of Good Husbandry (1576) as a versified set of agricultural precepts which derived entirely from Christian principles of probity and good life. ${ }^{6}$ In the seventeenth century, though, the influence of English attempts at didactic poetry in neo-Latin, alongside Rapin and Boileau's work on didactic poetry in France, prompted a renewed consideration of ancient didactic verse, and works by Lucretius, Manilius, Ovid and Virgil emerged in translation. ${ }^{7}$ Concomitantly, in the search for a poetic form which might successfully encapsulate the new scientific and philosophical knowledge of seventeenthand early-eighteenth-century amateur study, English poets began to write original didactic verse on the 
classical model, addressing topics as diverse as hunting, bee-keeping and wrestling. ${ }^{8}$ The most widely employed of the classical models was the Georgics, whose pervasive eighteenth-century influence has been attributed variously to the popularity of Dryden's translation and Addison's preface (1697), the malleability of the poem's attitudes for political and imperial applications, and the attractiveness of its ethic of industry and prudence. ${ }^{9}$ For British writers on agricultural improvement, the Georgics constituted a straightforward handbook of advice, whose precepts were directly transferrable from Augustan Rome to the situation of Enlightenment Britain. Prose treatises devoted purely to practical matters are littered with quotations or invocations of Virgilian method, and the same is true of Columella, Varro and other Roman agriculturalists.

Frans De Bruyn has written extensively on the 'debate Virgil's poem occasioned' in the eighteenth century on 'the scientific or technical merit of the agricultural instructions it conveyed' ${ }^{10}$

Contemporary readers of the Georgics, he argues, 'were predisposed to make strong cognitive claims for the poem' ${ }^{11}$ and writers of new agricultural treatises 'relied on the cultural imprimatur of Virgil in order to gain a friendly reception with the reading public'. ${ }^{12}$ For De Bruyn, this readerly approach amounted to the construction of a "Virgilian discourse' of agricultural science'. ${ }^{13}$ He points out that the trend of appealing to Virgilian authority to substantiate agricultural projects began as early as the establishment of the Georgical Committee in 1664, an early branch of the Royal Society dedicated to domestic agriculture. ${ }^{14}$ The Committee proposed at its first meeting that 'Heads of Inquiries' should be drawn from 'Georgicall Authors', in order to compose a practical questionnaire on the farming methods of different counties. ${ }^{15}$ This conflation of empirical enquiry with canonical observance became a commonplace of improvement writing from the turn of the century onwards. Several essays in Houghton's A Collection for the Improvement of Agriculture and Trade (1692-1703), for instance, are indebted to Book II of the Georgics on the cultivation of trees. In issue 470 (July 1701), Houghton discusses the proper method to transplant trees, and turns for practical guidance to 'Virgil, the best poet, and most experienc' $d$ in this argument', ${ }^{16}$ in order to supplement the rather more recent work of John Evelyn's Sylva (1664).

By the mid-eighteenth-century, deference to the precepts of the Georgics was an essential preamble of agricultural literature. Alexander Blackwell, an improver with considerable practical experience at the Duke of Chandos's estate in London, offers his New Method of Improving Cold, Wet, and Barren Lands (1741) with the dedicatory reminder that 'If the Treatise can boast of any Merit [...] it is chiefly owing to Columella and Virgil among the Ancients'. ${ }^{17}$ On the reclamation of clay soils, he explains that he has 'followed Columella and Virgil', because 'in what they say on this Head they are much more judicious and better to be relied on than most of the Moderns'. ${ }^{18}$ Along similar lines, the Scottish physician Alexander Hunter's Georgical Essays (1769) provide a scientific method for developing a new kind of compost, but the decision to use oil as the basis for the compost is substantiated by the fact that 'Virgil, indeed, has recommended the lees of oil as a manure'. The modifications that Hunter proposes are required merely because Virgil has omitted to consider 'the absolute necessity of rendering the oil miscible with water, by means of an alkaline salt'. ${ }^{19}$ This trend of blurring economic and literary activity continues into the nineteenth century, with the earliest reports produced by the Board of Agriculture (1793-1822). Under Sir John Sinclair and Arthur Young, the Board intended to gather nationwide surveys of current and improving agrarian practice, and sent regional commissioners to produce accurate contemporary reports of soil type, land usage, wages, prices and turnpikes. De Bruyn suggests that their findings represent the first overthrowing of 'Virgilian discourse' for nineteenthcentury 'forms of technical data gathering and analysis',${ }^{20}$ but several reports reveal that a reliance on 
classical letters still persists. An 1802 correspondent from Henley-on-Thames, for instance, observes that 'paring and burning' stubble ground appears to be an effective method of soil preparation, especially since 'Virgil appears no stranger to its use'. ${ }^{21}$

The extent to which this literal manner of reading the Georgics prevails is especially marked in midcentury translations, which produce versions of Virgil in line with contemporary agricultural theories and initiatives. ${ }^{22}$ The meaning of the Latin, for such translations, has economic as well as literary valences, because there are practical consequences for a farming audience if a mistranslation advises a crop to be sown incorrectly. A heated debate over the translation of Virgil's word 'planta', for instance, is the subject of Edward Holdsworth's Dissertation upon eight verses in the second book of Virgil's Georgics (1749), in which Holdsworth 'vindicates' Virgil from the agricultural mistakes for which other commentators hold him accountable. "Tis plain he uses the word indiscriminately for any shoots, sprigs, slips, or cuttings whatever, to be ingrafted, or planted', ${ }^{23}$ Holdsworth argues, and his object is to defend Virgil as a poet worth reading on the grounds of his being a farmer worth imitating. Blackwell, whose New Method produces translations of the Georgics 'in order to make Virgil speak like a man of Sense and a Farmer', ${ }^{24}$ is similarly concerned to attack misguided interpretations of ancient agricultural practice. 'Most if not all the Translators and Commentators on Virgil are against me, and suppose that Virgil meant only the burning a little Stubble on the Ground', he writes of Book I of the Georgics, and finds instead that 'VIRGIL uses the Word which they translate Stubble, frequently to signify the whole Stalk either of Corn or Grass before they are cut, which exactly corresponds to my Reading' ${ }^{25}$ This elicits the conclusion that 'some of our learned Translators (especially Mr DRYDEN) would have rendered VIRGIL of general Use to the Farmer had they been a little more conversant in Husbandry' ${ }^{26}$ A year after Blackwell's publication, a prose rendering of the Eclogues and Georgics by the Scottish schoolmaster James Hamilton appeared, advertised with 'such Notes and Reflexions as make him [Virgil] appear to have wrote like an excellent Farmer' ${ }^{27}$ This translation project was intended not only to be of practical value to the reader, but also to Hamilton himself: in the Dedication, he candidly admits to requiring an injection of capital to finance his own improvement projects. ${ }^{28}$

Pragmatic mid-eighteenth-century translations like Hamilton's are also contemporary with a set of original georgics in English on the subject of domestic regionality and agricultural improvement. Collectively, these georgics - Christopher Smart's The Hop-Garden (1752), Robert Dodsley's Agriculture (1753), John Dyer's The Fleece (1757) and Richard Jago's Edge-Hill $(1767)^{29}$ - represent a serious attempt to turn the Virgilian didactic tradition to the account of British agrarian development. They differentiate themselves consciously from earlier formal imitations of Virgil such as Philips' Cyder, and equally from the leisurely tastes of hunting and fishing handbooks like John Gay's Rural Sports (1713) and William Somerville's The Chase (1735). They share certain attitudes with the georgics of 1730s labouring-class poets (Stephen Duck, Mary Collier, Robert Tatersal and others), insofar as the writers of both tend to have a direct interest in the technical work in question. The mid-century poets, though, are capable of comprehending a broad macroeconomic vision of interconnected industry, as opposed to the localised and quotidian perspective of labouring-class writing; and, associated with this broader vision, to sound a new tone of enthusiasm, confidence and entrepreneurial dynamism. The extent to which this tone produced a successful reflection of contemporary economics is measured in the interest shown by innovators and specialists in the practical value of the poetry. The manufacturer Matthew Boulton, for instance, who ran a metallurgy factory near Birmingham, bought six copies of Edge-Hill, ${ }^{30}$ whilst the physician William Buchan used lines from The Fleece to praise a newly developed woollen 
'Patent Hosiery'. ${ }^{31}$ The market available for Virgilian translations of a practical bent appears to have existed in a comparable fashion for improvement georgic of the 1750s and 1760s.

Despite their contemporary reception, though, the mid-century georgics have received little sustained critical attention as a generic sub-set, and a fair amount of opprobrium for their tendency to literalness and 'low' concerns. 'You know there is already 'The Hop-Garden, a Poem'; and, I think, one could say a great deal about cabbage', ${ }^{32}$ Dr. Johnson remarked to Boswell, and most surveys of eighteenth-century poetry have, until fairly recently, adopted his tone: Leslie Stephen dismissed The Fleece as 'unreadable', ${ }^{33}$ and C.A. Moore has referred to it, somewhat ambivalently, as 'fortunately the most elaborate industrial poem [...] of all English literature' ${ }^{34}$ But more recent studies have examined the eighteenth-century georgic in English by means of a more sympathetic historical vision, which has resituated the genre within the various sets of socio-political relations in which it was originally written and read. Richard Feingold's study of 1978 is an early instance of the trend, considering The Fleece in the context of its enthusiastic promotion of Britain's trading empire. ${ }^{35}$

Since the 1980s, beginning with John Barrell's examination of georgic modes of work and eighteenth-century professional specialisation, ${ }^{36}$ a more nuanced series of arguments has emerged on the social valences of the genre. These arguments are largely the product, as Robert P. Irvine notices, of 'an interest in the role of empire in British culture in the period', ${ }^{37}$ and they include Karen O'Brien's study of 'imperial georgic' and colonial destinations of production, and Beth Fowkes Tobin's discussion of the role of georgic poetry in influencing attitudes towards the Tropics. ${ }^{38}$ Georgic has also been assessed for its contribution to domestic nationhood. Pat Rogers's essay on Cyder and Pope's WindsorForest (1713) studies 'politicized georgic' and the competing narratives of British history it promotes, ${ }^{39}$ whilst Rachel Crawford has analysed Jago's capacity in Edge-Hill to 'validate patterns of conservative landownership', ${ }^{40}$ and uncovered 'the essential Britishness of the agricultural project' by means of the 'traditional paternalist structure' underlying Dyer's The Fleece. ${ }^{41}$ Recently, Kevis Goodman has expanded the field of debate by electing to consider the eighteenth-century georgic as a 'register' of British social history, with emphasis on the 'moments of excess and dissonance', the telling 'instances of static in the flow of information', which disturb constructed mediations of reality. ${ }^{42}$ This article returns to the problem of georgic's 'mediating power ${ }^{43}$ and its capacity to redescribe historical circumstance consciously and consistently, but it de-emphasises political and imperial questions in favour of inspecting the genre in the context of progressive debates on British economic improvement. It seeks to relate the didactic function of georgic to the similarly practical usage of Virgil in agricultural literature and translations, and offers a new set of conclusions on the decline of the formal verse genre in English after the 1760s.

The particular attitudes that distinguish georgic of the mid-century are divergences from the characteristic ethical assumptions of Dryden's translation of Virgil and its early eighteenth-century imitations. The world-view of Virgil's Georgics, ably outlined by David Fairer, ${ }^{44}$ originates with Hesiod's founding myth of labour in Works and Days, which describes the process whereby golden and silver ages have been lost and replaced by an age of 'iron', condemning man to 'toil and misery'. ${ }^{45}$ Book I of the Georgics re-describes the same pattern, as Jove introduces man to labour and ends the Golden Age of indolence. ${ }^{46}$ In both organising myths, the human condition is a ceaseless struggle with an unpropitious environment, whose natural provisions are unsatisfactory and whose caprices are 
destructive. In the Georgics, chaotic storms interrupt labouring practice [I.431-58]; some kinds of soil are found to be intractably 'not fit to sow, / Nor will be tam'd or mended with the Plough' [II.323-4]; and in the case of the vast majority of endeavours, success 'is not [...] for Years assur'd' [I.284]. Work, in this unpromising landscape, is begun in the sure knowledge of incomplete achievement, but one of the central postulates of both Hesiod and Virgil's narratives is that it retains a positive value nonetheless. Men 'should embrace work-tasks in their due order', for 'work is no reproach, but not working is a reproach' ${ }^{47}$ Hesiod argues, and the Georgics emphasise the civilising and inventive capacities of industry. The imperative of hard graft possesses attendant social virtues, because in the course of technical refinement, 'arts are developed and the world can be conquered'. ${ }^{48}$

Work conquers its environment by means of observable and repeatable patterns, which impart a necessary appearance of structure to daily experience. ${ }^{49}$ The organising properties of labour's rhythms prevent formal Virgilian georgic from being merely an anatomy of imponderably hard work, and produce a semblance of achievement in a landscape continually turning back on itself. 'All things have their 'season', and success comes from knowing what is congenial to a task', ${ }^{50}$ Fairer writes of the approach to life that the Georgics recommend, and he offers a deliberately attenuated concept of 'success' to suit a cyclical concept of time. Accomplishment, in the Georgics, is merely a case of continuation, or of doing things at the proper time and precisely as they have always been done; which also means that it is perceived to be redemptive, not futile, that human achievement is governed by the returning rhythms of seedtime and harvest, instead of moving by progressive linear stages. In Dryden's translation, repeated references to the circularity of the seasons offer stable footholds in a changing landscape, and the annual calendar is understood to be a fixed set inside which labour is performed as it becomes necessary and possible:

The Peasant, innocent of all these Ills, With crooked Ploughs the fertile Fallows tills; And the round Year with daily Labour fills.

[II.738-40]

Dryden's 'round Year' is adopted as an underlying principle of structure in a number of early eighteenth-century georgics. The closing 'Hymn' to Thomson's The Seasons (1730) praises the 'rolling year' in its annual 'MYSTERIOUS Round', and addresses 'the GOD OF SEASONS as they roll' ;' Stephen Duck in The Thresher's Labour (1730) promises to 'sing the Toils of each revolving Year'; ${ }^{52}$ and Robert Tatersal, following Duck in The Bricklayer's Labours (1734), welcomes the way in which 'all the joyous Scene revolves again ${ }^{53}$ with the coming of spring. In a series of concentric circles, these greater rhythms are organised into synchronicity with the smaller repetitions of the individual working day, and the balanced tensions of the georgic farming calendar transform labour into a civilised (and civilising) check on the vicissitudes of the natural landscape.

The emblematic figure of this unchanging topography is Virgil's Corycian swain of Book IV of the Georgics, an old man unambitiously content with farming his small and difficult plot of land, and labouring according to the natural rhythms of each rotating season:

I chanc'd an Old Corycian Swain to know,

Lord of few Acres, and those barren too;

Unfit for Sheep or Vines, and more unfit to sow: 
Yet lab'ring well his little Spot of Ground,

[...]

To quit his Care, he gather'd first of all

In Spring the Roses, Apples in the Fall:

[IV.188-201

The attitudes this transmits to the eighteenth century are discussed at length in Maren-Sofie Rostvig's study of the beatus ille tradition, ${ }^{54}$ but it is worth isolating here the fact that the Corycian man is economically self-sufficient, and happy to be so: 'The little of his own, because his own, did please' [IV.199]. This investment in the ideal of complete household autarchy is an ethical survival from the seventeenth-century tradition of estate poetry, to which Dryden's translation and its imitations are especially indebted. ${ }^{55}$ Philips pictures a similar scene in Cyder:

\section{A frugal Man I knew,}

Rich in one barren Acre, which, subdu'd

By endless Culture, with sufficient Must

His Casks replenisht yearly. ${ }^{56}$

Inheriting a seventeenth-century moral economy of self-sufficiency, the early-eighteenth-century Virgilian georgic estate retains a conviction that industry means being content with 'one barren Acre', rather than maximising one's yield. A little hereditary plot of ground contains all that even the most enterprising of men could need, because delimiting one's ambitions is conceived as a source of labouring virtue. ${ }^{57}$

The mid-eighteenth-century georgic marks the point at which the morality attached to frugality and self-limitation is exchanged for the morality of improvement, and the georgic poet rejects the genre's traditional investment in modest ambition and difficult circumstances. Dodsley's Agriculture exemplifies the transition from an ethical to an economic concept of achievement by reworking Virgil's O fortunatos passage in Georgics II. 'O happy he! happiest of mortal men!' he begins, and praises the moral superiority of the contented subsistence farmer:

Tempted nor with the pride nor pomp of Power,

Nor pageants of Ambition,

$[\ldots]$

he plants his foot

With firmness on his old paternal fields,

And stands unshaken. ${ }^{58}$

Dodsley appeals to men of the city to embrace a country life, but he does so in a fashion that strains at the economic credibility of the concept of 'old paternal fields':

Turn to the arts, the useful pleasing arts

Of Cultivation; and those fields improve

Your erring fathers have too long despis'd. 
The literary and ethical point of the rura paterna is that it is inherited in precisely the form one's fathers left it, because its value lies in its timelessness. Dodsley's recognition here, though, is that once this approach to farming is judged by the standards of modern economic productivity, it begins to look selfdefeating. The desire to 'improve' one's land involves an acknowledgement that praise of limited ambition is fundamentally 'erring', and the poem's juxtaposition of the hard economic fact with the classical trope allows for an indication that those mistaken 'fathers' might be literary as well as familial.

In The Fleece, this rejection of economic modesty is elevated into an enthusiastic celebration of land improvement on a national scale. The four Books of the poem present variations on an attitude of unqualified economic confidence, which vaunts its own capacity to transform the natural landscape. Book II offers didactic precepts from 'the poet as improving agriculturalist', ${ }^{59}$ in John Goodridge's phrase, and it assumes an audience of landowners capable of raising the capital and manpower for improvement projects on a large scale. Dyer's discussion of the seventeenth-century reclamation of Deeping Fen and Bedford Level ('erst / A dreary pathless waste', before Francis Russell 'drain'd the rushy $f\left({ }^{\prime 60}\right.$ ) leads to an enthusiastic celebration of industry and technical accomplishment:

Ev'n such perfidious wilds, By labour won, have yielded to the comb The fairest length of wool.

'Tis art and toil

Gives nature value, multiplies her stores, Varies, improves, creates: 'tis art and toil Teaches her woody hills with fruits to shine, The pear and tasteful apple; decks with flow'rs And foodful pulse the fields.

For Virgilian georgic's patient attendance to what is necessary and possible within the given limitations of season, climate, soil and unforeseeable accident, Dyer substitutes an attitude to accomplishment that would value man's intervention ('art and toil') above any of nature's provisions. Work is not a simple matter of cooperating with circumstance and making the best of a bad job, in the way of Hesiod and Virgil's sense of necessary dissatisfaction; instead, it succeeds because it transforms pre-existing conditions and makes its own opportunities. In an age of commercial refinement, human happiness is the result of the 'value' that man brings to his environment.

Confidence in the farmer's capacity to increase the output of his land is, for Dyer, intimately connected to enclosure and aggregation, and his georgic urges landholders to abandon common-field subsistence farming for a more streamlined vision of productivity and efficiency. The worst species of wool will yield to farmers

who poorly toil,

Through a dull round, in unimproving farms

Of common-fields: inclose, inclose, ye swains;

[II.107-9]

The 'dull round' of 'unimproving' farming is a revision of Dryden's 'round Year' and Thomson's 'Mysterious Round' for a progressive age. Dyer associates the traditional Virgilian idea of the 
circularity of the seasons with the backwardness of those who 'joy in common-field' [II.110], and sets both against the exhortation to finessed production of 'inclose, inclose, ye swains'. For earlyeighteenth-century georgic's investment in a repetitive cyclical calendar, Dyer's georgic substitutes an ameliorative trajectory of increasing productivity, and this alteration of vision manifests itself in his manipulation of the poetic line. 'Besides', he writes of common-field farming,

in fields

Promiscuous held, all culture languishes;

The glebe, exhausted, thin supply receives;

Dull waters rest upon the rushy flats

And barren furrows: none the rising grove

There plants for late posterity, nor hedge

To shield the flock, nor copse for chearing fire;

[II.114-20]

Agricultural backwardness and stagnation, in this verse paragraph, are considered in formal terms as the results of repetition and circularity. Virgilian georgic provides cyclic patterns as reassuring points of contact with recognisable external phenomena. Here, though, the syntactic reiteration of 'none the rising grove $/ \ldots$ nor hedge $/ \ldots$ nor copse' presents repetition as obsessiveness, and forms a poetic line that habitually returns on itself rather than making progress, as the elliptical grammar of 'nor hedge / To shield the flock, nor copse for chearing fire' requires backtracking to locate the main verb 'plants'. Backwardness is conceived as a species of excess, or an unhealthy protraction of habits: the trailing extra syllable of the second line, for instance, allows the 'culture' of the metre to languish along with the fields, and the awkward enjambment of 'And barren furrows' is an appropriate instance of poetic neglect, rather than curtailment. Traditional practices, Dyer implies, may be observed for too long: the kinds of repetition and continuation to which the Virgilian farming calendar is wedded are merely invitations to decay, if they are not subjected to the invigorating morality of enclosure.

The attitude to progress this embodies is part of an intellectual interest in improvement for its own sake, regardless of the requirements of subsistence; and the readership it envisages is a literate class of professional farmers or landowners, equipped with sufficient leisure and understanding of theoretical matters to read around their subject (Dodsley, for instance, invokes 'the lore of fair Berkeria's Son' [II.49] in the second Canto of Agriculture, and directs his audience in a footnote to the works of 'The late Mr. Tull' [p.32n.] for further study). This interested readership is the particular addressee of Book II of Smart's The Hop-Garden, which offers a didactic overview of the various processes of hop-farming in Kent, and provides a strategy of optimum yield based on intelligent forward-planning. Its epigraph from Georgics I is on the importance of stockpiling and thinking ahead ('These all must be prepar'd, if Plowmen hope / The promis'd Blessing of a Bounteous Crop' [I.247-8]), and Smart's advice is intended for the planter who draws a distinction between the intellectual labour of his preparations for the year, and the physical labour of the workmen who will till the soil to his specifications. The role of the literate smallholder is to select his workforce carefully, and to employ his own energies on the task of facilitating the highest potential output of his land:

But first the careful planter will consult

His quantity of acres, and his crop,

How many and how large his kilns; ${ }^{61}$ 
The informative content of Smart's georgic is targeted towards the independent farmer or large landowner, interested in the theory of production and profit, but anxious to delegate the hard work. Physical labour, Smart argues, is intrinsically vulgar, and he describes the 'wild brutal crew' [II.91] who are hired to work as creatures of pure greed, 'inspir'd / By appetite of gain and lust of praise' [II.1612]. Instead of the ethical investment in process that characterises Virgilian georgic, where labour itself is a daily enacting of stoic and civilising attitudes, Smart proposes a new investment in outcome, which raises the objective profits of yield and machinery ('How many and how large his kilns') above any humanising effects of sweat and stamina.

Mid-century georgic notices new socioeconomic divisions between the kinds of men and women who perform agricultural work, and it addresses an emerging middle class of rural professionals with purchased property, alongside the traditional landowning elite and their happy swains. This expanded social perspective, though, is characteristically also allied to a broad vision of cooperative harmony at a macroeconomic level between different agrarian and industrial professional sectors. The georgic's projected addressee is no longer the retired man of the beatus ille tradition, in contemplative retreat from the world and its operations. Instead, the genre's precepts envisage an audience which is fundamentally involved, interested in a spectrum of economic functions and conscious of the variety of individual occupations required to animate the whole. ${ }^{62}$ The poet addresses this general interest by offering a confident vision of the professional unity of his nation and its trading networks abroad, as well as professing his own energetic interest in the technicalities of its composite branches.

Dyer seeks to provide a broad experience of interlinking trades in Book II of The Fleece, and his concern for the 'public weal' induces him to research thoroughly the occupations he describes:

With this desire, the merchant I attend;

By this impell'd, the shepherd's hut I seek, And, as he tends his flock, his lectures hear,

$[\ldots]$

Or turn the compass o'er the painted chart,

To mark the ways of traffic;

[II.504-10]

Work, in the georgic tradition, is considered as an organising principle of poetic structure as well as didactic subject matter, and Dyer's awareness of a range of cooperative professions finds expression at the level of the poetic line. In Book III, his description of the manufacture of a loom by different craftsmen makes a poetic unity of the division of tasks:

From some thick wood the carpenter selects

A slender oak,

$[\ldots]$

he shapes the sturdy beam,

The posts, the treadles; and the frame combines.

The smith, with iron screws, and plated hoops,

Confirms the strong machine, and gives the bolt

That strains the roll. To these the turner's lathe,

And graver's knife, the hollow shuttle add. 
Various professions in the work unite:

For each on each depends.

[III.111-20]

This passage is composed of a series of arranged elements and oppositions that resolve into unity. The distinct parts of the carpenter's work - 'the sturdy beam, / The posts, the treadles' - are neatly collected into a single 'frame' by means of the delayed verb 'combines', whilst the enjambed fluidity of 'and gives the bolt / That strains the roll' moves through the line break with a momentum that enables and finesses the chain of production. The manner in which the syntax of the smith's 'iron screws, and plated hoops' balances against the 'turner's lathe, / And graver's knife' organises a formal compliance from two distinct areas of work, and the effect is reinforced by the delaying of 'add', which gathers up the various processes into a single mode of production. The chime of 'combines' and 'Confirms' offers a harmony of enterprise at the beginning and end of lines, and across multiple kinds of manufacture; and the total effect is to comprehend as poetic work the idea that 'each on each depends'.

This vision of a general dependence, and the related acknowledgement that each profession is as vital as every other to the broader economic prospect, involves for the poet a necessary demystification and reintegration of his own trade. One 'determining ingredient of georgic', for Kurt Heinzelman, is its 'advocacy of a composite socioeconomic order', and this totalising perspective 'defines writing as a vocation within the largest possible political economy that includes farming, soldiering, statesmanship [and] artisanal production'. ${ }^{63}$ Jago's Edge-Hill, a topographical poem of Warwickshire and its noble estates, is also a keen investigation of agriculture, mining and metallurgy, and it offers an ideal of national macroeconomic unity similar to Dyer's. But Jago's vision is complicated by a sense for the way in which his poem's own processes and specialisms might come to be no more than another interested link in a larger economic chain. Describing the labour of the metalworker at his 'midnight Toil', ${ }^{64}$ Jago illustrates how his labour relates to that of 'the Graver's pointed Steel' and the 'artful Pencil', as well as, finally, the printing trade:

Thine too, of graceful Form, the letter'd Type!

The Friend of Learning, and the Poet's Pride!

Without thee what avail his splendid Aims,

And midnight Labours?

[III.570-7]

The 'midnight Toil' of the metalworker is intimately linked with the 'midnight Labours' of the poet, and a single broad chain of production binds their efforts together. Dependent upon the most mechanical of trades, the poet's work is comprehended by the same economic terms that treat of occupations traditionally conceived of as unfit to bear comparison with the realm of letters. Poetry is fundamentally interested, and unembarrassedly so, in the same way that the engraver's art is interested in that of the metalworker who fashions his tools. Writing a georgic about industrial production, Jago is keenly conscious of the distance he has travelled from the Virgilian field, and the kinds of simple farming work that are the substance of its imagery and its ethical stance. But the poem makes a point of observing that metalwork, in its basic and more refined forms, underpins all branches of agriculture: it is Warwickshire's 'native British Ore' [III.582] that allows 'the Silver's Edge' to shear the corn and 'the Silver Plowshare' to turn the soil [III.601-5]. Edge-Hill broadens and complicates the scope of georgic's economic interests, and reintegrates the business of writing poetry into professional life. 
Reshaping the traditional concerns of georgic to suit the new material of agricultural improvement, though, proves to be problematic. The mid-century georgic of Smart, Dodsley, Dyer and Jago, regardless of the comprehensive way in which it differentiates itself from earlier Virgilian imitations, is always recognisably of the same heritage, and alludes deliberately and seriously to a variety of traditional georgic tropes. The information it conveys, though, is part of a new and self-conscious scientific discourse of agricultural experiment, which is concerned to question the value of inherited knowledge by trial and experience. Advice on agricultural improvement is couched as the data of empirical observation rather than the handed-down precepts of previous generations, and this is the case from the earliest seventeenth-century pamphlets on agrarian matters. In 1663, for instance, writing on clover as a new fodder crop, the river engineer and agriculturalist Andrew Yarranton warns that one great 'obstruction to good Husbandry and improvement of Lands, is a too stiff adhering to old Customs'. ${ }^{65}$ English, Irish and Welsh farmers suffer, he writes, by 'retaining those usages and methods in Husbandry which never any man pretended any good reason for, but were [...] handed from one to another, till they had got the venerable name of Antiquity'. ${ }^{6}$

Yarranton's distrust of 'old Customs' is a common theme of improvement handbooks for the next century. Tull's The Horse-Hoing Husbandry (1733) and its follow-up piece, A Supplement to the Essay on Horse-Hoing Husbandry (1735), are both emphatically in favour of the new empirical approach to gathering and imparting information, and inclined accordingly to disclaim any reliance on classical precepts. Farming, Tull argues in The Horse-Hoing Husbandry, belongs to an intellectual category fundamentally different to the kind of discipline which profits from myth-making and ritualistic inheritance. 'No Canon having limited what we shall think in Agriculture', he writes, 'nor condemned any of its Tenets for Heresy, every Man is therein a Free-Thinker' ${ }^{67}$ Agricultural advice, in fact, is trustworthy to precisely the degree to which it has changed over the years, because 'Truth is like Gold, which the more it is tryed the brighter it appears, being freed from Dross' ${ }^{68}$ Blackwell, in his New Method for the improvement of wetlands, complains similarly of the loose practice of his contemporaries, who have 'not confined themselves to Narratives of real Practice and Experiments'. Mere 'Hypotheses and Theories', he argues, 'are no more to be advanced in Husbandry than in Natural Philosophy'. ${ }^{69}$ William Ellis's hugely popular farming almanac, The Modern Husbandman (1731), is particularly dismissive of 'obstinate Blades' who farm by adhering to 'some useless, vamped up, false old Theory [...] wrote by Authors not capable of judging of their Truth or Falsehood'. A 'Practice [...] in the Art of Agriculture', Ellis writes, is the 'chief Means' whereby such farmers could be qualified 'for making a better Distinction and Judgement'. ${ }^{70}$ Later in the century, Hunter's record of his method for producing a new species of compost in the Georgical Essays proceeds along even more self-consciously scientific lines, and notes that the author 'took care to reason upon proper data, carefully avoiding every degree of partiality to my system'. ${ }^{71}$

The information deriving from this developing empirical tradition is the subject matter conveyed by the didactic function of the mid-century georgic. But there are unavoidable perspectival difficulties with containing scientifically accurate and experientially observed detail in a traditional poetic framework of imitation and allusion; and the georgic of improvement, as the final flourishing of formal Virgilian verse in English, marks the moment at which the much-praised flexibility of the genre begins to undergo untenable levels of strain. The poet's dual obligation to practical experience and handed- 
down forms is sustainable only by awkward sleights of hand, and the specificity of the information he communicates threatens to overwhelm the georgic's common formulae of trope and diction.

In The Fleece, Dyer organises his new material on improvement by means of various recognisably Virgilian vignettes, which work to reconcile the currency and precision of the information with the allusive framework of the whole. In Book I, he provides an updated eighteenth-century version of the Georgics' Corycian swain as a vehicle for his advice on drainage and burning brambles for fertilisation:

I knew a careful swain,

Who gave them to the crackling flames, and spread

Their dust saline upon the deep'ning grass:

And oft with labour-strengthen'd arm he delv'd

The draining trench across his verdant slopes.

[I.108-12]

Goodridge has pointed out the contradictions involved in associating Virgil's symbolic figure (an 'exemplum [...] of modest retirement and harmonious adaptation to the limitations of the environment') with an eighteenth-century culture of ambition and aggrandisement. 'Dyer's swain', he observes, 'is by contrast a heroic figure, physically exerting himself with 'labour-strengthen' $\mathrm{d}$ arm' to change the environment'. ${ }^{72}$ The strain of the comparison, though, runs deeper than this, because it involves Dyer's transformation of an empirical field of knowledge - the greater yield resulting from strategies of drainage and fertilisation - into a literary-philosophical category based on an unquestioned allusive inheritance. It involves, too, an ideological strain in the substance of the comparison, where a contemporary morality of growth and improvement is conceptualised by a completely antithetical ethics of delimitation and modesty. There are reasons, which have nothing to do with his historical moment, why Virgil's Corycian man would not have dug a 'draining trench'.

A similarly problematic sleight of hand occurs in Book II, when Dyer describes experiments in sowing rotation and the introduction of fodder crops:

But why recount our grassy lawns alone,

While ev'n the tillage of our cultur'd plains,

With bossy turnep, and luxuriant cole,

Learns thro' the circling year their flocks to feed.

[II.389-92]

The reference here is to recent endeavours across the eastern counties of England, which used root crops in a four-course rotation system as a means of 'cleaning' the land in between sowings of cereals, and harvested them as fodder for sheep. This system not only eliminated fallow periods, but also ensured that livestock could be kept alive over the winter months ('thro' the circling year') by feeding on 'turnep' and 'cole'. The availability of these new Dutch fodder crops redressed the prevailing insufficiency of feed to sustain winter herds. ${ }^{73}$ In Dyer's georgic, though, the progressive spirit of forward-planning associated with these kinds of farming techniques is encapsulated by the traditional Virgilian motif of the 'circling year', which has the effect of transforming systemic improvement into a poetic mythology of ritual and repetition. The enlightened farmer who transcends seasonal limitations by artificial means is elided with the stoic peasant of Dryden's 'round year', and the dynamic of progress is contained by a celebration of unchanging seasonality. 
Broader systemic developments like crop rotations are treated in mid-century georgic alongside more focussed vignettes, which address specific new inventions and mechanisms. These are particular interests and hobbyhorses of the poet, enthusiastically championed and knowledgeably explained; and they demand the kind of technically precise discussion that does not sort comfortably with the literary set-pieces available to formal georgic. In the second Book of The Hop-Garden, for instance, Smart describes the process of drying the picked hops in a kiln. His local experience of Kentish farming allows him to illustrate his account with an up-to-date description of Dr. Stephen Hales's ventilating fan (1742), an efficient drying mechanism invented the year Smart began work on his georgic: ${ }^{74}$

Constant and moderate let the heat ascend;

Which to effect, there are, who with success

Place in the kiln the ventilating fan.

Hail, learned, useful man!

$[\ldots]$

if thy industry

Has serv'd the hopland cause, the Muse forebodes

This sole invention, both in use and fame,

The mystic fan of Bacchus shall exceed.

[II.201-9]

Despite Smart's knowledgeable grasp of Hales's system, he is unwilling to praise the invention by the economic standards of efficiency and yield for which it was originally devised. Instead, he aligns it with the literary merit of 'The mystic fan of Bacchus', for which an authorial footnote directs the reader to Book I of the Georgics. The ventilator is a technically advanced instrument made for a particular practical purpose, but the Virgilian allusion has the effect of turning it into an emblem, and making its processes representative rather than unique. The difficulty of containing specific new data in a traditional poetic frame is addressed by providing a literary precedent for economic innovation. Hales's mechanism is conceived as a contemporary variation on an ancient trope.

A similar transformation occurs when Hales's inventions reappear in Agriculture as the scientific basis of Dodsley's allegory of the farming year. Juan Christian Pellicer's attentive study of the poem notices the cautious balance that Dodsley tries to strike between poetic decorum and the 'increasingly specialised character and mechanistic orientation of eighteenth-century science', ${ }^{75}$ but he describes Dodsley's approach to the new material as 'diplomatic' and generalist, avoiding a problematic engagement with the specificities of improvement. ${ }^{76}$ The appeal to Hales's theories, though, is just such a specific and direct engagement with innovation, and it marks one point at which the cautious 'consensus' between information and generic framework collapses. The Goddess of Nature, leading a masque-like procession of the seasons, offers up a celebratory hymn to the heavens:

Let all the Powers of Nature raise the Song!

[...]

When now the genial warmth Earth's yielding breast

Unfolds. Her latent salts, sulphureous oils,

And Air, and Water mixt; attract, repel,

And raise prolific ferment.

[I.422-9] 
'The philosophy of this hymn', Dodsley explains in a footnote, 'is built on that experimental foundation, laid by the learned and ingenious Dr. Hales, in his Vegetable Statics' [p.23n.]. Vegetable Statics (1727), the first volume of Hales's Statical Essays, seeks to formulate a theory of the motion of fluids in plants. ${ }^{77}$ Dodsley's hymn is full of the appropriate terminology: 'sulphureous oils', 'ductile juice' and 'ascending tubes' evince an impression of thorough scientific comprehension. But as the hymn continues, Hales's 'experimental foundation' is suddenly exchanged for the foundation of literary pedigree:

The wandering eye delighted roves untir'd.

The hawthorn's whitening bush, Pomona's blooms,

And Flora's pencil o'er th'enamell'd green,

The varying scenes enrich.

$$
\text { [1.452-5] }
$$

Dodsley invokes the customary mythologised features of early-eighteenth-century georgic landscape ('Flora's pencil o'er th' enamell'd green', for instance, recalls Pope's Windsor-Forest, where 'blushing Flora paints th'enamel'd Ground ${ }^{78}$ ), and juxtaposes them with the new empirical accuracy of Hales's findings. An enthusiastic desire to know precisely how the things of the earth work, 'sulphureous oils' and all, is juggled uncomfortably with a modest sense that all one can do is rename them, or appeal to the traditional ways in which they have been represented. The didactic function of the poem exists by means of an ideological contradiction, whereby the impulse to currency and accuracy in the subject matter is frustrated by the evasive generality of trope and allusion.

The problem of Flora and Vegetable Statics describes in miniature a larger crisis in georgic of the midcentury, which has to do with the incompatibility of an economic morality of expansion with a literary morality of self-limitation, and the incompatibility of contemporary work - technical, experimental, specialist - with the customary tropes of Virgilian tradition. The increasing complexity of eighteenthcentury professional life, and the intransigent nature of the information required to master it, suggest together one reason for the gradual decline of didactic poetry in English from the mid-century onwards, and may offer a useful addition to other available theories of eighteenth-century genre change. ${ }^{79}$ Smart, Dodsley, Dyer and Jago appear to have experienced common kinds of problems with communicating and teaching the new methods of agricultural production; and the difficulties they encounter, as well as the strategies they contrive to combat them, are symptomatic of a slippage of confidence in the period about the basic assumption underpinning the didactic tradition, a sense 'of the unity of knowledge and of the verbal means available to express it' ${ }^{80}$

This decline of confidence has to do with the amount and kind of information that obtains in an age of rapid industrial and agricultural progress, and the related proliferation of specialist functions required to maintain levels of advanced output. The kinds of socioeconomic conditions that the mid-century georgic attempts to encapsulate are those outlined by social theorists of the Scottish Enlightenment, who offer a model of developing civilisation based on the division of tasks. David Hume, Adam Ferguson and Adam Smith describe the manner in which the economic function of the individual progresses from the primitive but complete personality of the barbarous ages and the classical republics (eras in which all free men were capable of shifting between the roles of warrior, farmer and public citizen, as circumstances required), to a situation of commercial refinement whereby the increasingly 
minute division of professional tasks allows a single craft to 'ingross the whole of a man's attention', as Ferguson explains in An Essay on the History of Civil Society (1767). ${ }^{81}$ Wealth accrues from the individual's dedication to his own allotted function in cooperation with all the other individuals in any given branch of production, but associated with this process of subdivision is a proportionate decline in the individual's ability to perceive consciously the degree to which he is cooperating with a larger whole. ${ }^{82}$ 'Nations of tradesmen', Ferguson writes, 'come to consist of members who, beyond their own particular trade, are ignorant of all human affairs'. Formed, 'like the parts of an engine, to concur to a purpose, without any concert of their own', they exist in a complex set of socioeconomic relations of which they have little sense, and are 'blind [...] to any general combination'. ${ }^{83}$ The knowledge they possess is of too specific a kind to make other operations and functions comprehensible.

The didactic project of the mid-century georgics, according to this idea of society, is immensely ambitious. Encapsulating all the knowledge relevant to the hop-farming business, for instance, involves a detailed understanding of multiple processes of production, whilst offering comprehensive specialist advice on the numerous arms of manufacture through which wool passes on its way to the international market would be nothing short of miraculous. Poetry hopes to convince of special claims on the mass of economic data by promising to extract a 'general combination' from individualised endeavour, and to arrange isolated social operations so that they are newly recognisable as related (Dyer's interlinking of the labours of the blacksmith, turner, carpenter and engraver is one such attempt). The problem with this totalising function, though, arises as a matter of perspective: how is the poet to be both usefully interested and necessarily disinterested in the various occupations he describes? Providing information on several subjects is to provide nothing of practical value on any of them, because the complexity of commercial society is such that there is no conceivable vantage point from which the poet can survey a wide economic prospect in sufficient detail. 'In matters of particular profession, industry, and trade, the experienced practitioner is the master, and every general reasoner is a novice, ${ }^{84}$ Ferguson argues, and there is no room for a didactic poet who is a novice.

Mid-century georgic has its strategies to combat the problem: by omitting to acknowledge the identities of specific addressees, the differentiated interests of a shepherd and a wool manufacturer, for instance, may be usefully elided, and the separate branches of agricultural knowledge required by landowners and tenant farmers are combined in order to conceal individual inadequacies. But this is a temporary solution to a crisis of literary confidence, which also signals a change in ethical approach. Virgilian georgic finds unsatisfactory knowledge a source of admirable resignation and moral character, and it offers its didactic function as a generic correlative for delimited kinds of curiosity and ambition. The problems Smart, Dodsley, Dyer and Jago encounter, and which make their georgics of improvement the last of their kind, stem universally from the application of this classical didactic attitude to an age for which knowledge is only admirable where it is extensive, specific and (ideally) complete.

\footnotetext{
Notes

${ }^{1}$ Anon., Select Essays on Commerce, Agriculture, Mines, Fisheries, and Other Useful Subjects (London, 1754), p.126.

2 A.H. John, 'The Course of Agricultural Change, 1660-1760', in W.E. Minchinton (ed.), Essays in Agrarian History, 2 vols. (Newton Abbot, 1968), vol. 1, p.245.
} 
3 John Barrell, The Idea of Landscape and the Sense of Place, 1730-1840 (Cambridge, 1972), p.64.

${ }^{4}$ See Joan Thirsk (gen. ed.), The Agrarian History of England and Wales, 8 vols. (Cambridge, 1967-2000), vol. VI: 1750-1850, ed. by G.E. Mingay (1989), p.574; G.E. Mingay, English Landed Society in the Eighteenth Century (London, 1963), p.189-201.

${ }^{5}$ Arthur Young, A Six Weeks Tour, through the Southern Counties of England and Wales (1768), p.21-2; see also Alexander Hunter, Georgical Essays (London, 1769), p.66-7.

${ }^{6}$ Thomas Tusser, Five Hundred Points of Good Husbandry (London, 1576).

${ }^{7}$ Dwight L. Durling, Georgic Tradition in English Poetry (New York, 1935), p.5-14.

${ }^{8}$ Respectively William Somerville's The Chase (1735), Joshua Dinsdale's Modern Art of Breeding Bees (1740) and Nicholas James's Wrestling (1742).

${ }^{9}$ On the useful flexibility of the georgic, see John Chalker, The English Georgic: A study in the development of a form (London, 1969), p.10-15; John Barrell, The Dark Side of the Landscape: The Rural Poor in English Painting 1730-1840 (London, 1980), p.12; Kurt Heinzelman, 'Roman Georgic in the Georgian Age: A Theory of Romantic Genre', Texas Studies in Literature and Language 33 (1991), p.184; David Fairer, English Poetry of the Eighteenth Century (Harlow, 2003), p.79-80; David Fairer, 'Persistence, Adaptation, and Transformations in Pastoral and Georgic Poetry' in John J. Richetti (ed.), The Cambridge History of English Literature, 1660-1780 (Cambridge, 2005).

${ }^{10}$ Frans De Bruyn, 'Reading Virgil's Georgics as a Scientific Text: The Eighteenth-Century Debate between Jethro Tull and Stephen Switzer', ELH 71 (2004), p.662.

${ }^{11}$ Frans De Bruyn, 'Eighteenth-Century Editions of Virgil's Georgics: From Classical Poem to Agricultural Treatise', Lumen: Selected Proceedings from the Canadian Society for Eighteenth-Century Studies 24 (2005), p.150.

${ }^{12}$ Frans De Bruyn, 'From Georgic Poetry to Statistics and Graphs: Eighteenth-Century Representations and the 'State' of British Society', The Yale Journal of Criticism 17 (2004), p.107.

${ }^{13}$ Frans De Bruyn, 'From Virgilian Georgic to Agricultural Science: An Instance in the Transvaluation of Literature in Eighteenth-Century Britain’ in Albert J. Rivero (ed.), Augustan Subjects: Essays in Honor of Martin C. Battestin (Newark, 1997) (1997), p. 51.

${ }^{14}$ Ibid., p. 51.

${ }^{15}$ Lennard, 'English Agriculture under Charles II', p. 23-4.

${ }_{17}^{16}$ John Houghton, A Collection for the Improvement of Husbandry and Trade, 4 vols. (1692-1703; repr. 1727-8), vol. 3, p.149.

${ }^{17}$ Alexander Blackwell, A New Method of Improving Cold, Wet, and Barren Lands (London, 1741), p.i.

18 Ibid., p.iv.

${ }^{19}$ Hunter, Georgical Essays, p.45.

${ }^{20}$ De Bruyn, 'From Virgilian Georgic to Agricultural Science', p.48. The relationship between literature and statistics and data-gathering is explored in more detail in De Bruyn, 'From Georgic Poetry to Statistics and Graphs', p.107-39.

${ }^{21}$ Henry Protheroe, 'An Essay on the best Means of converting Grass Land to Tillage' in Anon., Communications to the Board of Agriculture, 7 vols. (London, 1797), vol. 3, p.489.

22 See De Bruyn, 'Eighteenth-Century Editions of Virgil's Georgics', p.152-61, for a study of the practical possibilities of Virgilian translation.

${ }^{23}$ Edward Holdsworth, A Dissertation upon Eight Verses in the Second Book of Virgil's Georgics (London, 1749), p.3.

${ }^{24}$ Blackwell, A New Method of Improving Cold, Wet, and Barren Lands, p. 51.

${ }^{25}$ Ibid., p.51-4.

${ }^{26}$ Ibid., p. 55.

${ }^{27}$ Virgil [James Hamilton], Virgil's Pastorals Translated into English Prose; as also his Georgicks (Edinburgh, 1742), p.i.

${ }^{28}$ See ibid., p.vii-viii.

${ }^{29}$ The Hop-Garden is edited as part of Smart's collected poems (Karina Williamson (ed.), The Poetical Works of Christopher Smart, 6 vols. (Oxford, 1980-), vol. 4 (1987)), and a critical edition of The Fleece has recently been produced: see John Dyer, The Fleece: A Poem in Four Books, ed. by John Goodridge and Juan Christian Pellicer (Cheltenham, 2007). However, no edition of Edge-Hill or Agriculture is yet available. Juan Christian Pellicer, 'The Georgic at Mid-Eighteenth Century and the Case of Dodsley's 'Agriculture", Review of English Studies 54 (2003), p.67, provides a discussion of the poem's relative neglect. Two more contemporary georgics, John Armstrong's The Art of Preserving Health (1744) and James Grainger's The Sugar-Cane (1764), have recently become available in scholarly editions. See, respectively, Adam Budd (ed.), John Armstrong's The Art of Preserving Health: Eighteenth-Century Sensibility in Practice (Farnham, 2011); John Gilmore, The Poetics of Empire: A Study of James Grainger's The Sugar-Cane (London and New Brunswick, 2000).

30 Crawford, Poetry, Enclosure and the Vernacular Landscape, p.150.

${ }^{31}$ William Buchan, A Letter to the Patentee (London, 1790), p.5.

${ }^{32}$ John Wilson Croker (ed.), Boswell's Life of Johnson: Including their Tour to the Hebrides (London, 1848), p.486.

${ }^{33}$ Quoted in John Goodridge, Rural Life in Eighteenth-Century English Poetry (Cambridge, 1995), p.92. 
${ }^{34}$ C.A. Moore, 'Whig Panegyric Verse, 1700-1760', PMLA 41 (1926), p. 384.

${ }^{35}$ Richard Feingold, Nature and Society: Later Eighteenth-Century Uses of the Pastoral and Georgic (Sussex, 1978), p.87-115.

${ }^{36}$ John Barrell, English Literature in History 1730-1780: An Equal, Wide Survey (London, 1983), Ch.1.

37 Robert P. Irvine, 'Labor and Commerce in Locke and Early Eighteenth-Century English Georgic', ELH 76 (2009), p.963.

Pellicer, 'The Georgic at Mid-Eighteenth Century', p.88, criticises the 'tendency in recent criticism' to link the trajectory of mid-century georgic 'too firmly' to 'imperialist tendencies', and to 'political developments' more broadly.

${ }^{38}$ Karen O’Brien, 'Imperial georgic, 1660-1789' in Gerald MacLean, Donna Landry and Joseph P. Ward (eds.), The Country and the City Revisited: England and the Politics of Culture, 1550-1850 (Cambridge, 1999), p.160-79; Beth Fowkes Tobin, Colonizing Nature: The Tropics in British Arts and Letters, 1760-1820 (Philadelphia, 2004), p.32-55.

39 Pat Rogers, 'John Philips, Pope and Political Georgic', MLQ 66 (2005), p.414.

${ }^{40}$ Rachel Crawford, Poetry, Enclosure, and the Vernacular Landscape, 1700-1830 (Cambridge, 2002), p.143-7.

${ }^{41}$ Rachel Crawford, 'English Georgic and British Nationhood', ELH 65 (1998), p.123-4, 135.

${ }^{42}$ Kevis Goodman, Georgic Modernity and British Romanticism: Poetry and the Mediation of History (Cambridge, 2004), p. 2-3, 9, 64. Goodman modifies the emphasis of John Barrell, Karen O'Brien and others on discerning in georgic 'the imposition of ideas that convert places to landscape' (p.57), preferring an account of the genre as susceptible itself to the imposition of 'the noise of history' (p.64).

43 Ibid., p.9.

${ }^{44}$ I draw my account of the 'ethical assumptions' and 'world-view' of the Georgics chiefly from Fairer, English Poetry of the Eighteenth Century, p.90-2; but also from Chalker, The English Georgic, p.26-7, Anthony Low, The Georgic Revolution (Princeton, 1985), p.12, and Heinzelman, 'Roman Georgic in the Georgian Age', p.187-8. Fairer's most recent work on the genre ("Where Fuming Trees Refresh the Thirsty Air': The World of Eco-Georgic', Studies in Eighteenth-Century Culture 40 (2011), especially p.205-8) relates georgic portrayals of nature's difficulty and inscrutability to the kind of ecological respectfulness more closely associated with Romanticism.

45 Works and Days in M.L. West (trans.), Hesiod: Theogony and Works and Days (Oxford, 1999), p.40-2.

${ }^{46}$ See Virgil's Georgics, I.183-6, in James Kinsley (ed.), The Poems of John Dryden, 4 vols. (Oxford, 1958), vol. 2, p.923.

Further references (to book and line number) are to this edition.

${ }^{47}$ West (trans.), Hesiod: Theogony and Works and Days, p. 46.

${ }^{48}$ Chalker, The English Georgic, p. 26.

${ }^{49}$ David Fairer, “'The Year Runs Round': The Poetry of Work in Eighteenth-Century England' in Lorna Clymer (ed.), Ritual, Routine, and Regime: Repetition in Early Modern British and European Cultures (Toronto, 2006), p.164.

${ }^{50}$ Ibid., p. 164.

51 'A Hymn', 1.2, 21, 93, in James Thomson, The Seasons, ed. by James Sambrook (Oxford, 1981), p. 254-8.

52 Stephen Duck, The Thresher's Labour, 1.8, in William Christmas (ed.), Eighteenth-Century English Labouring-Class Poets, 1700 1800: Volume I, 1700-1740 (London, 2003), p.139.

53 Robert Tatersal, The Bricklayer's Labours, 1.109, in ibid., p. 287.

${ }^{54}$ Maren-Sofie Rostvig, The Happy Man: Studies in the Metamorphoses of a Classical Ideal: Volume II, 1700-1760, $2^{\text {nd }}$ edn. (Oslo, 1971).

${ }^{55}$ On the trope of self-sufficiency in country house poetry, see G.H. Hibbard, 'The Country House Poem of the Seventeenth Century', Journal of the Warburg and Courtauld Institutes 19 (1956), p.164-5, and William A. McClung, The Country House in English Renaissance Poetry (Berkeley, Los Angeles and London, 1977), p.118-22.

${ }^{56}$ John Philips, Cyder. A Poem in Two Books, ed. by John Goodridge and J.C. Pellicer (Cheltenham and Gloucester, 2001), II.117-20, p.30.

${ }^{57}$ On the importance of the rura paterna for the early-eighteenth-century imagination, see Maynard Mack, The Garden and the City: Retirement and Politics in the Later Poetry of Pope, 1731-1743 (Toronto and London, 1969), p.100-7.

58 Robert Dodsley, Public Virtue: A Poem. In Three Books. I. Agriculture. II. Commerce. III. Arts (London, 1753), Book the First: Agriculture, I.313-18, p.18. Further references (to canto and line number) are to this edition.

59 Goodridge, Rural Life in Eighteenth-Century English Poetry, p.114.

${ }^{60}$ John Dyer, The Fleece. A Poem in Four Books, ed. by Goodridge and Pellicer, II.165-71, p.40. Further references (to book and line number) are to this edition.

${ }^{61}$ The Hop-Garden: A Georgic, II.74-6, in Williamson (ed.), The Poetical Works of Christopher Smart, vol. 2, p.57. Further references (to book and line number) are to this edition.

62 Barrell, English Literature in History 1730-1780, p.24-5.

${ }^{63}$ Heinzelman, 'Roman Georgic in the Georgian Age', p. 202.

${ }^{64}$ Richard Jago, Edge-Hill (1767), III.568, p.116. Further references (to book and line number) are to this edition.

65 Andrew Yarranton, The Improvement improved by a second edition (London, 1663), 'To the Reader'. 
${ }^{66}$ Ibid., 'To the Reader'.

67 Jethro Tull, The Horse-Hoing Husbandry (London, 1733), p.ii.

68 Ibid., p.ii.

${ }^{69}$ Blackwell, A New Method of Improving Cold, Wet, and Barren Lands, p.ii, v.

${ }^{70}$ William Ellis, The Modern Husbandman, or, the practice of farming, 4 vols. (London, 1731; repr. 1744), vol. 2, p.16-7.

${ }^{71}$ Hunter, Georgical Essays, p.42.

72 Goodridge, Rural Life in Eighteenth-Century English Poetry, p.119-20.

${ }^{73}$ See E.L. Jones, 'Agriculture and Economic Growth in England, 1660-1750: Agricultural Change', in Minchinton (ed.), Essays in Agrarian History, vol. 1, p.207-9.

74 See Chris Mounsey, 'Christopher Smart's The Hop-garden and John Philips's Cyder: A Battle of the Georgics? Mideighteenth-century poetic discussions of authority, science and experience', Journal for Eighteenth-Century Studies 22 (1999), p.77. For Hales's own account of his invention, see Stephen Hales, A Description of Ventilators (London, 1743), p.129-53.

75 Pellicer, 'The Georgic at Mid-Eighteenth Century', p.78.

${ }^{76}$ Ibid., p.79-80.

${ }^{77}$ See Stephen Hales, Statical Essays: Containing Vegetable Staticks (London, 1731), p.2-4.

${ }^{78}$ Windsor-Forest, 1.38, in John Butt (gen. ed.), The Twickenham Edition of the Poems of Alexander Pope, 11 vols. (London and New Haven, Conn., 1939-69), vol. 1, p.151.

${ }^{79}$ Pellicer, 'The Georgic at Mid-Eighteenth Century', p.91-2, gives a literary explanation for georgic decline, arguing that respective developments in scientific discourse and sentimental poetry made 'other genres, in verse and in prose [...] more apt' vessels for the georgic's subject matter. Heinzelman, 'Roman Georgic in the Georgian Age', p.199-200, takes a historically determinist approach, proposing that under George III 'the Georgic becomes so entwined with the didactic purposes of Georgian economic improvement and foreign policy that it becomes unthinkable as an aesthetic norm', hamstringed by 'an unexpected and relentlessly singular referentiality'.

${ }^{80}$ De Bruyn, 'From Virgilian Georgic to Agricultural Science', p.63. Heinzelman, 'Roman Georgic in the Georgian Age', p.190, argues that the late eighteenth-century decline of confidence in 'texts that overtly espouse an edifying purpose' is an early manifestation of Romanticism, as a 'literary and critical practice that valorises irony' and distrusts 'clarity'.

${ }^{81}$ See Adam Ferguson, An Essay on the History of Civil Society. 1767, ed. by Duncan Forbes (Edinburgh, 1966), but also 'Of Refinement in the Arts', in David Hume, Essays Moral, Political, and Literary, ed. by Eugene F. Miller, $2^{\text {nd }}$ edn. (Indianapolis, 1987), p.268-80, and Adam Smith, An Inquiry into the Nature and Causes of The Wealth of Nations, ed. by Edwin Cannan, 2 vols. (London, 1904; repr. Chicago, 1976), vol. 2, p.213-24.

${ }^{82}$ See Barrell, English Literature in History 1730-1780, p.25-33.

${ }^{83}$ Ferguson, An Essay on the History of Civil Society, p. 182.

${ }^{84}$ Ibid., p. 144. 